\title{
Occurrence of two distinct lineages of the freshwater jellyfish Craspedacusta sowerbii (Hydrozoa: Limnomedusae) in Italy
}

\author{
Massimo Morpurgo, ${ }^{1 *}$ Peter Schuchert, ${ }^{2}$ Samuel Vorhauser, ${ }^{3}$ Renate Alber ${ }^{3}$ \\ ${ }^{1}$ Museum of Nature South Tyrol, Via Bottai / Bindergasse 1, 39100 Bolzano, Italy; ${ }^{2}$ Natural History Museum of Geneva, Route de \\ Malagnou 1, 1208 Geneva, Switzerland; ${ }^{3}$ Biological Laboratory, Agency for Environment and Climate Protection of the Autonomous \\ Province Bolzano South Tyrol, Via Sottomonte 2, 39055 Laives (BZ), Italy
}

\begin{abstract}
The freshwater jellyfish Craspedacusta sowerbii Lankester 1880 is a cryptic cosmopolitan invasive species, which occurs in all continents except Antarctica. Recent molecular studies suggest the existence of at least three very different genetic lineages of Craspedacusta: the "sowerbii", the "kiatingi", and the "sinensis" lineages. We report the presence of both medusae and polyps of this alien taxon in the Large Lake of Monticolo / Montiggl, a meso-eutrophic natural lake in the Province of Bolzano / Bozen in Northern Italy. Molecular analyses of mitochondrial 16S sequences showed that this population belongs to a different lineage than that recently described for Sicily (Southern Italy). Therefore, there are two different genetic lineages of C. sowerbii in Italy. In the Large Lake of Monticolo / Montiggl medusae were observed in 6 consecutive summers (2015 - 2020), from July to September. All the examined medusae were males. The stomach content analyses showed that zooplanktonic copepods and cladocerans with size range between 0.3 and $0.8 \mathrm{~mm}$ were the preferred prey of medusae. Polyps of C. sowerbii were recorded in the lake on the zebra mussel Dreissena polymorpha in shallow water and on the underside of artificial substrates. The analyses of zebra mussels would therefore be a simple method to check for the presence of the polyp stage of $C$. sowerbii in various aquatic environments.
\end{abstract}

\section{INTRODUCTION}

The first description of the freshwater jellyfish Craspedacusta sowerbii (Cnidaria: Hydrozoa: Limnomedusae) was published after its discovery in a water lily tank in Regent's Park, London, England in 1880 (Lankester, 1880). The number of species in the genus Craspedacusta is still disputed (Jankowski et al., 2008). As in other hydromedusae, their high morphological plasticity makes it difficult to identify diagnostic traits that can be reliably used to differentiate

Corresponding author: massimo.morpurgo@naturmuseum.it

Key words: Freshwater medusa; polyps; invasive species; genetic lineages; $16 \mathrm{~S}$

Edited by: Alberto Doretto, Dept. of Environmental and Life Sciences, University of Piemonte Orientale "Amedeo Avogadro", Alessandria, Italy

Received: 25 June 2020.

Accepted: 18 November 2020 .

This work is licensed under a Creative Commons Attribution NonCommercial 4.0 License (CC BY-NC 4.0).

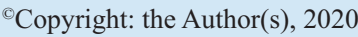

Licensee PAGEPress, Italy

J. Limnol., 2021; 80(1):1974

DOI: 10.4081/jlimnol.2020.1974 species. Molecular markers like $16 \mathrm{~S}$ is thus an essential tool to analyze in the study of jellyfish invasions. Recent molecular studies suggest the existence of at least three very different lineages of Craspedacusta: the "sowerbii", the "kiatingi", and the "sinensis" lineages (Fritz et al., 2009; Zou et al., 2012; Karaouzas et al., 2015; Schifani et al., 2018; Oualid et al., 2019). The hydromedusa reported as $C$. sowerbii has been asserted to be native to the Yangtze River system in China (Kramp, 1961), but a conclusive, global phylogeographic study has never been made. It is a cosmopolitan invasive taxon, occuring in all continents except Antarctica (Dumont, 1994; Jankowski, 2001; Jankowski et al., 2008). After its discovery in England, the taxon was recorded in numerous other European countries (Arbačiauskas and Lesutienè, 2005; Lundberg et al., 2005; Fritz et al., 2007; Karaouzas et al., 2015; Minchin et al., 2016; Ciutti et al., 2017; MedinaGavilán and González-Duarte, 2018), in North America (Acker and Muscat, 1976; DeVries, 1992), in Central America (Moreno-Leon and Ortega-Rubio, 2009), in South America (Failla Siquier et al., 2017; Caputo et al., 2018), in Asia (Bekleyen et al., 2011; Gasith et al., 2011; Lewis et al., 2012); in Africa (Rayner, 1988; Oualid et al., 2019), in Australia (Thomas, 1950) and in New Zealand (Boothroyd et al., 2002).

In this paper, we report biological observations on $C$. sowerbii made in a Northern Italian lake, including genetic data showing that this population belongs to a different lineage than one from Sicily (Southern Italy) recently described in Schifani et al. (2018). 


\section{METHODS}

\section{Study area}

The Large Lake of Monticolo/Montiggl (from $46^{\circ} 25^{\prime} 16^{\prime \prime}$ to $46^{\circ} 25^{\prime} 37^{\prime \prime} \mathrm{N}$ and from $11^{\circ} 17^{\prime} 16^{\prime \prime}$ to $\left.11^{\circ} 17^{\prime} 41^{\prime \prime} \mathrm{E}\right)$ is located at $492 \mathrm{~m}$ asl in the Bolzano Province, Italy (Fig. S1A). It has a surface area of $178,400 \mathrm{~m}^{2}$ and a volume of about $1,490,000 \mathrm{~m}^{3}$. Its maximum length is $757 \mathrm{~m}$, its average width is $236 \mathrm{~m}$ and its maximum water depth is about $12.5 \mathrm{~m}$ (Thaler and Tait, 1981a) (Fig. S1B). It is a natural lake of glacial origin. The unique surface tributary of the lake is the effluent of the overlying Small Lake of Monticolo/Montiggl (22 $\mathrm{m}$ altitude difference), which is located about 400 meters away (Fig. S1C). The tributary is only active after heavy rainfall. The water supply of the Large Lake depends mainly on rain and underground springs. The unique effluent (Angelbach) is located on the southern shore. The Small Lake of Monticolo/Montiggl (from $46^{\circ} 25^{\prime} 41^{\prime \prime}$ to $46^{\circ} 25^{\prime} 50^{\prime \prime} \mathrm{N}$ and from $11^{\circ} 17^{\prime} 38^{\prime \prime}$ to $11^{\circ} 17^{\prime} 50^{\prime \prime} \mathrm{E}$ ) is a natural glacial lake and is located at $514 \mathrm{~m}$ asl. The lake has a surface area of $52,100 \mathrm{~m}^{2}$ and a volume of about $517,000 \mathrm{~m}^{3}$. Its maximum length is $316 \mathrm{~m}$, its average width is $165 \mathrm{~m}$ and its maximum water depth is $14.8 \mathrm{~m}$ (Thaler and Tait, 1981b). Tributaries are absent and the water supply depends on rain and underground springs.

The Large Lake and the Small Lake of Monticolo/Montiggl are classic dimictic lakes (Thaler and Tait, 1987). Normally, from the end of December until the end of February or beginning of March the surfaces of the lakes are covered by ice. In summer, there is thermal stratification of the water with a thermocline at a depth of about $5 \mathrm{~m}$ and the temperature of the epilimnion reaches $24-26^{\circ} \mathrm{C}$.

Tab. 1 contains the most important chemical and physical water parameters of the first five meters of depth from 2015 to 2019 of Large Lake of Monticolo/Montiggl. Chemical data classify the lake as a meso-eutrophic water body.

The Large Lake of Monticolo/Montiggl has a huge number of different rotifer species. The most common species in the period from 2010 to 2015 with an average individual density above 10 individuals per liter include: Ascomorpha ecaudis, Filinia terminalis, Gastropus stylifer, Hexarthra mira, Kellicottia longispina, Keratella cochlearis and Polyarthra dolichoptera. The following crustaceans were found during the same period: Alona affinis, Bosmina longirostris, Bosmina longispina, Ceriodaphnia quadrangula, Cyclocypris ovum, Cyclops strenuus, Cyclops vicinus, Daphnia longispina, Diaphanosoma brachyurum, Eudiaptomus gracilis and Mesocyclops leuckarti (source database of the Biological Laboratory, Agency for Environment and Climate Protection of the Autonomous Province Bolzano South Tyrol, Italy, 2020).

The alien invasive zebra mussel Dreissena polymorpha (Pallas, 1771) has been present in the lake for at least 20 years (Morpurgo and Thaler, 2002) and is currently very abundant.

Tab. 1. Main chemical and physical water parameters of the first $5 \mathrm{~m}$ of depth in Large Lake of Monticolo/Montiggl in the years 20152019.

\begin{tabular}{|c|c|c|c|c|c|c|}
\hline Parameter & Unit & 2015 & 2016 & 2017 & 2018 & 2019 \\
\hline $\max$ Temp & ${ }^{\circ} \mathrm{C}$ & 26.1 & 24.6 & 25.9 & 25.8 & 25.2 \\
\hline $\max \mathrm{pH}$ & $\nabla$ & 8.59 & 8.64 & 8.59 & 8.54 & 8.58 \\
\hline Conductivity & $\begin{array}{c}\mu \mathrm{S} \mathrm{cm}^{-1} \\
20^{\circ} \mathrm{C}\end{array}$ & 317 & 308 & 303 & 297 & 300 \\
\hline MRP & $\mu \mathrm{g} \mathrm{L}^{-1}$ & 1 & 2 & 2 & 3 & 3 \\
\hline TP & $\mu \mathrm{g} \mathrm{L}^{-1}$ & 20 & 33 & 17 & 16 & 14 \\
\hline TOC & $\mathrm{mg} \mathrm{L}^{-1}$ & 5.9 & 6.0 & 6.1 & 5.7 & 5.7 \\
\hline $\mathrm{NNO}_{3}$ & $\mu \mathrm{g} \mathrm{L}^{-1}$ & 21 & 22 & 17 & 14 & 20 \\
\hline $\mathrm{NNH}_{4}$ & $\mu \mathrm{g} \mathrm{L}^{-1}$ & 123 & 170 & 110 & 65 & 109 \\
\hline $\mathrm{TFe}$ & $\mu \mathrm{g} \mathrm{L}^{-1}$ & 27 & 23 & 35 & 30 & 30 \\
\hline $\mathrm{Chl} \mathrm{a}$ & $\mu \mathrm{g} \mathrm{L}^{-1}$ & 4.1 & 2.7 & 1.4 & 4.2 & 2.6 \\
\hline $\mathrm{SO}_{4}$ & $\mathrm{mg} \mathrm{L}^{-1}$ & 8.90 & 9.35 & 10.78 & 10.71 & 10.65 \\
\hline $\min \mathrm{O}_{2}$ & $\mathrm{mg} \mathrm{L}^{-1}$ & 7.33 & 5.32 & 7.82 & 7.57 & 4.70 \\
\hline $\max \mathrm{O}_{2}$ & $\mathrm{mg} \mathrm{L}^{-1}$ & 9.43 & 12.33 & 9.71 & 9.89 & 10.31 \\
\hline $\mathrm{TN}$ & $\mu \mathrm{g} \mathrm{L}^{-1}$ & 537 & 602 & 547 & 467 & 510 \\
\hline
\end{tabular}

max Temp, maximum temperature; max $\mathrm{pH}$, maximum $\mathrm{pH}$; MRP, mean molybdate reactive phosphorus; TP, mean total phosphorus; TOC, mean total organic carbon; $\mathrm{NNO}_{3}$, mean nitrate nitrogen; $\mathrm{NNH}_{4}$, mean ammonium nitrate; TFE, mean total iron; Chl a, mean chlorophyll a; $\mathrm{SO}_{4}$, mean sulfate; min $\mathrm{O}_{2}$, oxygen minimum; max $\mathrm{O}_{2}$, oxygen maximum; $T N$, mean total nitrogen. 


\section{Sampling}

This study was carried out between August 2015 and September 2020. In this timeframe, 30 sampling and visual census scuba dives were performed in the Large Lake of Monticolo / Montiggl for collection and abundance estimation of $C$. sowerbii medusae. In total, 63 specimens were gently collected by hand with wide-mouth glass jars with screw-on lids or with transparent plastic bags by a scuba diver during daylight hours from the water-column between 1 and $6 \mathrm{~m}$ of depth. During the scuba dives, water temperature in Celsius degrees $\left( \pm 1^{\circ} \mathrm{C}\right)$ and depth in meter $( \pm 0.1 \mathrm{~m})$ were measured by a scuba dive computer Suunto Vyper. A medusa of $C$. sowerbii voucher specimen, collected on the $30^{\text {th }}$ of July 2017 and fixed in ethanol $70 \%$, was deposited in the zoological collection of the Museum of Nature South Tyrol, Bolzano / Bozen, Italy (C. sowerbii collection number NMS EVV5). Two specimens of $C$. sowerbii medusae were collected on the $22^{\text {nd }}$ of July 2018 and were fixed in ethanol $96 \%$ for molecular analyses. A total of 30 medusae were collected for sex determination on the $9^{\text {th }}$, the $11^{\text {th }}$ and the $18^{\text {th }}$ of August 2019. In the laboratory they were maintained alive in aquarium at 24$25^{\circ} \mathrm{C}$ for about three weeks. The jellyfish were fed live and frozen cyclopoid copepods. Within three days of their collection, tiny biopsies of fresh gonad tissue were taken from live medusae. The sex of medusae was determined by observing these tiny fresh gonadal tissues with the use of a microscope at magnification $100 \times$ and $400 \times$ as reported in the literature (Pérez-Bote et al., 2006; Lundberg et al., 2007; Xu and Wang, 2009). Photographs of medusae gonads were taken under a Leica DMR microscope with objective HCX PL Fluotar 40x/0.75, PH 2.

For the analyses of stomach contents, 30 medusae were collected: 15 specimens on the $13^{\text {th }}$ of September 2019 and 15 specimens on the $19^{\text {th }}$ of September 2019. Immediately after sampling they were fixed in ethanol $70 \%$. In the laboratory, the medusae were dyed with pink colored ethanol $90 \%$ to facilitate the visual search for prey. The umbrella diameter of the medusae was measured putting graph paper under the petri dish containing the medusae and stomachs were dissected using tweezers under a stereo microscope Olympus SZX 12 at a 90 -fold magnification. Prey was identified and counted under a bright-field microscope Olympus BX40 at magnification $400 \times$.

To estimate medusae abundance, the scientific diving visual census technique for pelagic organisms was used, in accordance with Heine (2011). Underwater timed transects were performed swimming with scuba diving equipment at a constant depth (between 2 and $3 \mathrm{~m}$ ) and a constant speed for a specific length of time (60 minutes). All counted medusae were recorded underwater on a slate with indication of depth and water temperature of observation point. During the visual census dives the underwater visibility was variable between approximately 2 and $5 \mathrm{~m}$.

According to the literature (Stanković and Ternjej, 2010), we searched for polyps of $C$. sowerbii on zebra mussels $D$. polymorpha in the lake. On the $14^{\text {th }}$ August 2017, in total 24 zebra mussels were collected randomly by hand by a scuba diver in the Large Lake of Monticolo/Montiggl. The zebra mussels were between 15 and $25 \mathrm{~mm}$ long. Twelve specimens were collected at a depth of $1 \mathrm{~m}$. The zebra mussels were in the shade, attached to bottom side of a step of the ladder of a wooden pier. Twelve zebra mussels were collected from a rock at a depth of $5 \mathrm{~m}$.

To determine the presence of $C$. sowerbii polyps by qualitative analysis, on the $2^{\text {nd }}$ of June 2018 and on the $25^{\text {th }}$ of April 2019, zebra mussels were also collected in the Small Lake of Monticolo/Montiggl at a depth between 1 and $1.5 \mathrm{~m}$ from the underside of the steps of a ladder attached to a wooden pier. All zebra mussel samples were gently placed into $0.5 \mathrm{~L}$ glass jars filled to approximately $70 \%$ of capacity with lake water. In the laboratory, the samples were kept in the jars without lids at room temperature $\left(24-25^{\circ} \mathrm{C}\right)$ and with a cycle of 14 hours of light and 10 hours of darkness. Within 10 days after the sampling date, the live zebra mussels were then examined on all sides under a stereomicroscope, at magnifications between $20 \times$ and $45 \times$, to ascertain whether there were polyps present, as reported in the literature (Stanković and Ternjej, 2010; Duggan and Eastwood, 2012). The polyps were not fed during the days in the laboratory. The microscopic photographs of polyps were taken under a stereomicroscope Leica M205 A.

\section{Molecular analyses}

The methods for obtaining about $600 \mathrm{bp}$ of the mitochondrial $16 \mathrm{~S}$ gene as well as maximum likelihood analyses are given in Schuchert $(2014,2018,2019)$. In addition to the two medusae samples from Large Lake of Monticolo/Montiggl, we obtained a tissue sample of a female medusa Craspedacusta sowerbii from Sicily kindly provided by Federico Marrone and Luigi Naselli-Flores, University of Palermo (Italy). The animal originated from the same pool and the same population described by Schifani et al., (2018). The resulting partial 16S sequences have been deposited in GenBank under the accession numbers MT107153 to MT107155. For our comparisons we retrieved aligned further $16 \mathrm{~S}$ sequences of Craspedacusta species from GenBank and ran a maximum likelihood analysis using the substitution model $\mathrm{HKY}+\mathrm{G}$ proposed by Modeltest. As outgroup we choose a sequence of Limnocnida tanganjicae (EU293972), the most similar known sequence not derived from a Craspedacusta species (comp. Oualid et al., 2019). The origin of the material used to determine the sequences in GenBank is unfortunately 
not always given in the metadata. Where possible, we tried to obtain the missing ones by contacting the authors (sequences EU293971, EU293974, and KY077294) or inferred them from the publications they were used in (see also Oualid et al., 2019).

\section{RESULTS AND DISCUSSION}

\section{Molecular analyses}

The two medusae from the Large Lake of Monticolo/Montiggl had two identical mitochondrial 16S sequences (Fig. 1), while the one from Sicily was quite different from them and clustered in a separate clade (clade 2 in Fig. 1). The medusae from Lake of Monticolo/Montiggl had the same sequences as hydroids from two locations found in Switzerland and differed only in one position from two other sequences, one from Germany and one from Morocco. The medusa sample from Sicily (see Material and Methods) clustered in a second clade (Fig. 1), together with geographically widely separated samples originating from the Americas to China. This separation for the mitochondrial 16S (Fig. 1) into two separate clusters has also been observed for the mitochondrial COI gene and the nuclear ITS marker (Fritz et al., 2009; Zhang et al., 2009; Karaouzas et al., 2015; Schifani et al., 2018; Fuentes et al., 2019; Oudalid et al., 2019). Our clade 1 (Fig. 1) corresponds to the "kiatingi" cluster, clade 2 to the "sowerbii" cluster of Fritz et al. (2009) and Schifani et al. (2018). Some of the taxonomic implications are discussed in Oudalid et al. (2019) and also the other works mentioned above. The new evidence on the potential presence of more than one invasive lineage in the genus Craspedacusta is an emergent aspect which has been little discussed until now and which deserves more attention. Although the concordance of mitochondrial and genomic lineages suggests that two distinct Craspedacusta species could be present in Europe and also that they may be spreading to new freshwater bodies around the world (Karaouzas et al., 2015; Fuentes et al., 2019), the available data are still preliminary and not conclusive. A similar situation was observed in Schuchert 2014 for the marine hydroid Plumularia setacea. As discussed in that work, it is desirable to search for places were both lineages occur in sympatry, allowing the application of a biological species concept. As there are two lineages present in Italy, one in the very north and the other in Sicily, it is possible that there is a contact zone anywhere between these two localities where both lineages co-occur.

\section{Polyps}

In August 2017, polyps of C. sowerbii were recorded in the Large Lake of Monticolo/Montiggl on the shells of zebra mussels $D$. polymorpha collected at a depth of $1 \mathrm{~m}$ (Tab. S1). The polyps were between 0.6 and $1.0 \mathrm{~mm}$ high (Fig. S2-A). On the zebra mussels collected at a depth of $5 \mathrm{~m}$ no polyps of C. sowerbii were found. In June 2018, 15 polyps ( 7 individual polyps and 4 colonies of two polyps) were recorded on one $20 \mathrm{~mm}$ long zebra mussel collected in the Small Lake of Monticolo/Montiggl at 1 $\mathrm{m}$ depth at $21^{\circ} \mathrm{C}$ water temperature. In April 2019, in this lake polyps of $C$. sowerbii were found again on zebra mussels collected at a depth of $1.5 \mathrm{~m}$ at $14^{\circ} \mathrm{C}$ water temperature (Tab. S1). From the year 1946 (Stefanelli, 1948), the occurrence of $C$. sowerbii has been documented in at least 40 freshwater ecosystems in Italy, but almost exclusively based on observations of the medusa stage and not of the polyp stage (Ramazzotti, 1962; Rossi and Lodi, 1971; Badino and Lodi, 1972, Cotta Ramusino, 1972; Trentini, 1993; Stefani et al., 2010; Groppali, 2013; Morpurgo and Alber, 2015; Ciutti et al., 2017; Schifani et al., 2018). Probably, the species may have a far wider distribution in Italy (Ciutti et al., 2017) than previously thought due to often-overlooked polyps (Duggan and Eastwood, 2012).

Stanković and Ternjej (2010) described the association between polyps of $C$. sowerbii and the zebra mussel $D$. polymorpha as commensalism. The above-mentioned authors believe that the polyps of $C$. sowerbii benefit from $D$. polymorpha, as the water current created by the bivalve feeding brings food directly to the polyps. Polyps of $C$. sowerbii prefer areas without heavy sedimentation and surfaces without heavy algal growth (Acker and Muscat, 1976; Duggan and Eastwood, 2012). In the present study, polyps of $C$. sowerbii were detected on shells of $D$. polymorpha without algae or detritus, attached in shade to the underside of the steps of submerged stairs (this position prevents sediment accumulation) in shallow water (between 1 and $1.5 \mathrm{~m}$ depth). The polyps were found in the two lakes on zebra mussels in April, June and August with water temperature from $14^{\circ} \mathrm{C}$ to $24^{\circ} \mathrm{C}$. Considering the wide distribution of $D$. polymorpha in Italy (Cianfanelli et al., 2010), the analyses of these bivalves could be a good method to check for the presence of polyps of $C$. sowerbii in various aquatic environments. The search for the polyps on zebra mussels can be carried out even when the water temperature is below $19^{\circ} \mathrm{C}$, while medusae are usually observable when the water temperature is between $19^{\circ} \mathrm{C}$ and $30^{\circ} \mathrm{C}$ (Acker and Muscat, 1976; DeVries, 1992).

\section{Underwater visual census of medusae}

In August 2015, medusae of C. sowerbii were recorded for the first time in the Large Lake of Monticolo/Montiggl (Morpurgo and Alber, 2015) (Fig. S2B). In the following five years 2016-2020, from midJuly to the beginning of October with water temperature 
from $19^{\circ} \mathrm{C}$ to $26^{\circ} \mathrm{C}$ medusae were sighted in the lake. The number of observed medusae in 60 minutes of scuba diving ranged from 1 to a maximum of 36 specimens in September 2019 (Fig. 2). The increase in jellyfish numbers in summer 2019 compared to other years could be related to the prolonged period of epilimnion water temperature at $25-26^{\circ} \mathrm{C}$. Experiments in laboratory have proven that $26^{\circ} \mathrm{C}$ is the optimal temperature for medusae growth (Folino-Rorem et al., 2016). The meteorological summer 2019 in the Bolzano Province, Italy, was characterized by particularly high temperatures $\left(3^{\circ} \mathrm{C}\right.$ more than the average of the temperatures of the century 19012000), ranking third in the historical series that dates back to 1850 , just behind the record summers of the years 2003 and 2015 (Peterlin et al., 2019). Production of medusae is related to increased water temperatures, although other environmental factors may also be important such as abundance of food and water quality (Acker and Muscat, 1976; DeVries, 1992).

Although in 2019 up to 36 medusae were observed in

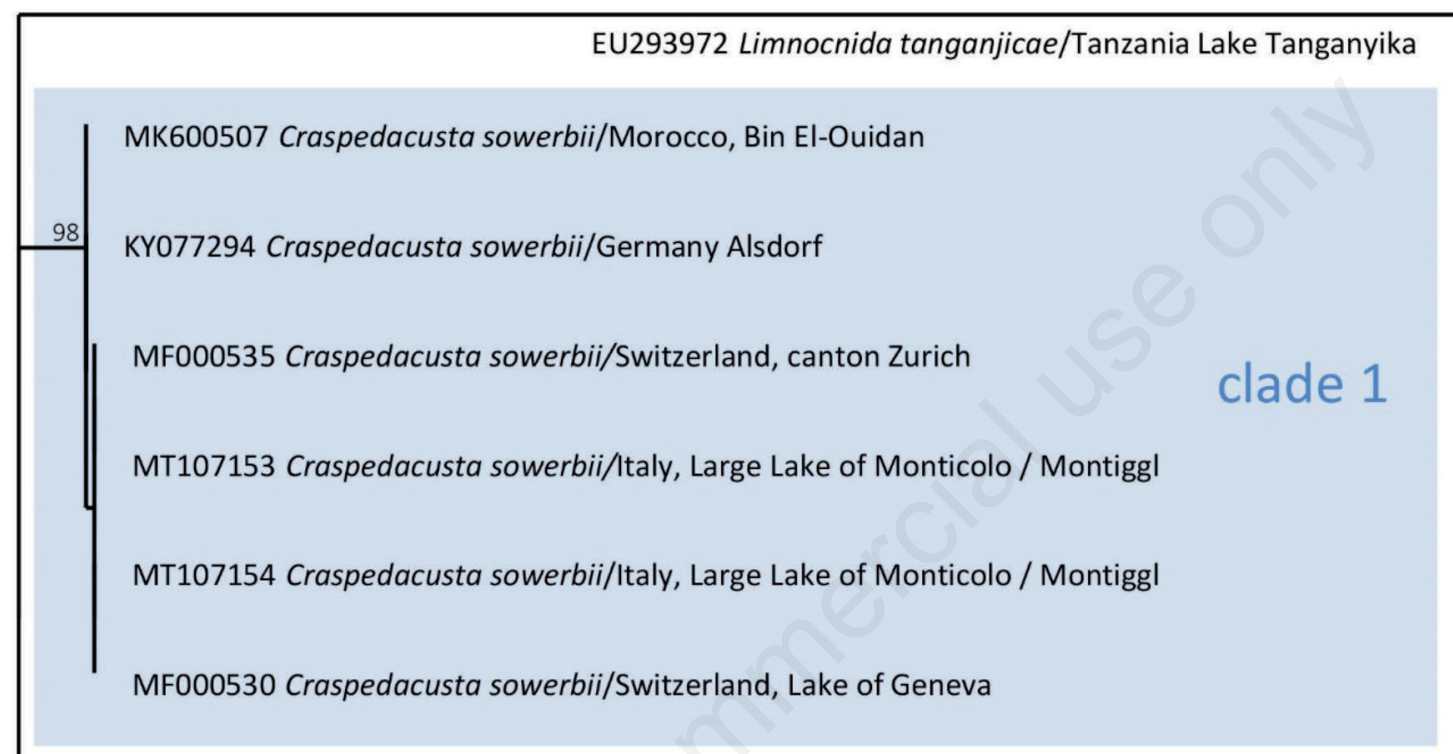

Outgroup

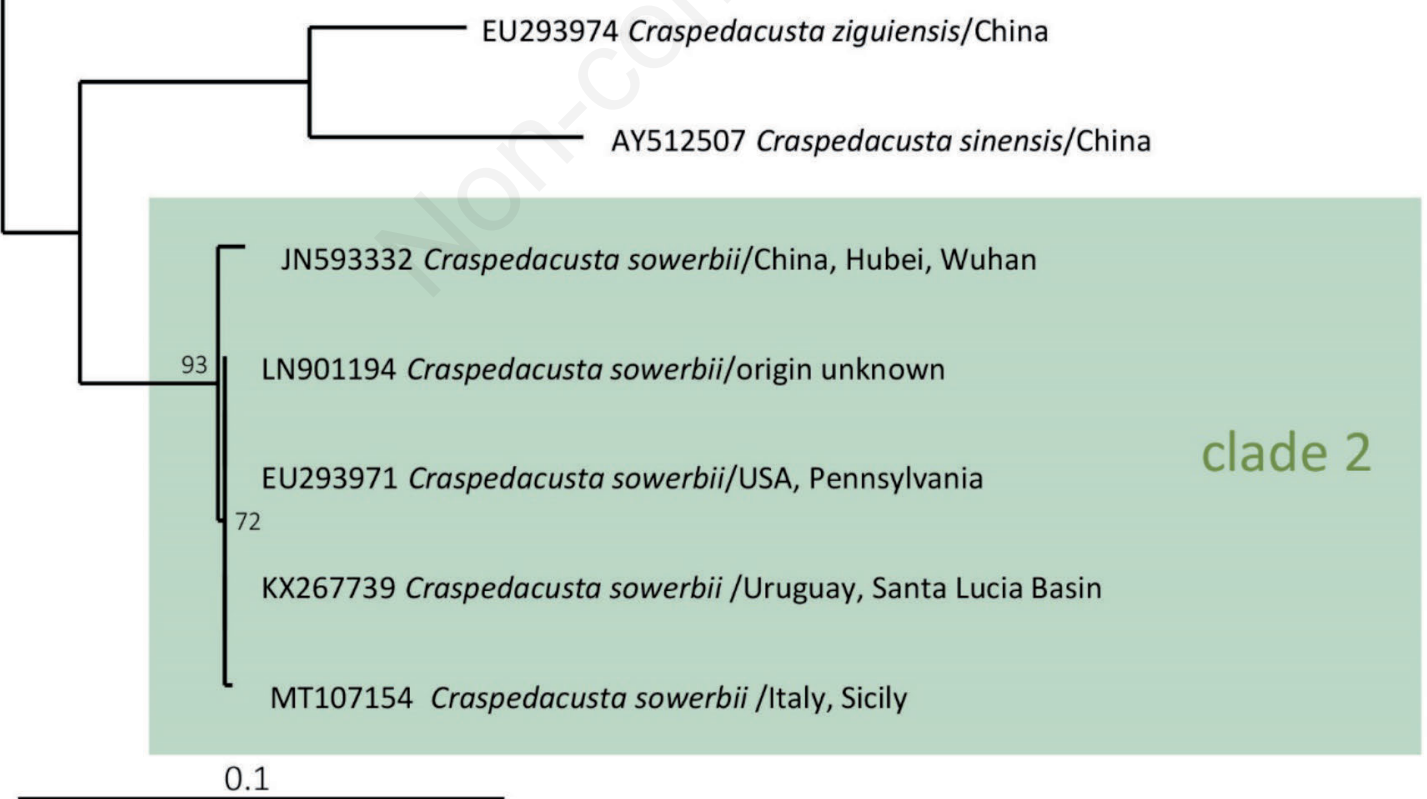

Fig. 1. 16S maximum likelihood phylogenetic tree of Craspedacusta species (medusae or polyps) obtained with PhyML (HKY $+\mathrm{G}$ model) and based on $610 \mathrm{bp}$ positions of the mitochondrial 16S gene. Node-support values are bootstrap values of 100 pseudoreplicates (shown only if $>70 \%$ ). For more review, see text. The taxon legend consists of the EMBL accession code followed by the species name and specimen origin. 
the Large Lake of Monticolo/Montiggl in 1 hour of underwater visual census, this is a relatively small abundance and could not be considered as a real jellyfish bloom. These data correspond to a density of much less than one individual per square meter or per cubic meter. Freshwater jellyfish blooms with very high densities are reported in the literature: Arbačiauskas and Lesutiene (2005) observed up to 20-30 individuals per square meters in an old water-filled gravel pit in Lithuania. In Germany, Dumont (1994) reported medusae densities of up to 30 individuals per cubic meter in an artificial quarry reservoir near Ulm and Jankowski (2000) counted even over 400 individuals per square meter in a eutrophic pond near Aachen.

In the Large Lake of Monticolo/Montiggl, medusae were observed in 6 consecutive summers from 2015 to 2020 with water temperature from $19^{\circ} \mathrm{C}$ to $26^{\circ} \mathrm{C}$, while other studies in Italy typically report the record of a single year or the sightings of 2 or at most 3 years (Ciutti et al., 2017). The present study confirms that scuba diving represents a good method for monitoring and sampling of freshwater jellyfish, as reported in the literature (Fritz et al., 2007; Oualid et al., 2019).

\section{Sex determination of medusae}

The 30 medusae collected in August 2019 (water temperature $26^{\circ} \mathrm{C}$ ) for sex determination had umbrella diameters between 12 and $20 \mathrm{~mm}$ and had four mature gonads. All the examined medusae were males. Under microscope at magnification $400 \times$ the gonad tissue of a medusa male was recognizable as a uniform tissue of small cells. At the borders of the uniform tissue numerous mobile spermatozoa were identifiable (Fig. S2C). The results of gonads analyses indicate that the $C$. sowerbii population of Large Lake of Monticolo/Montiggl most probably consists of males only. Usually, outside China single sexed populations are observed, and the sexual reproduction seems infrequent (Acker and Muscat, 1976; DeVries, 1992). Some studies report unisexual populations of only female medusae (Trentini, 1993; Pérez-Bote et al., 2006; Minchin et al., 2016), whereas in other aquatic ecosystems only males were recorded (Lankester, 1880; Boothroyd et al., 2002; Lundberg et al., 2005; Lundberg et al., 2007).

\section{Stomach contents of medusae}

The analysis of stomach contents showed that crustaceans were the preferred prey of medusae of $C$. sowerbii at the time of investigation (Tab. S2). The 30 examined medusae had umbrella diameters between 10 and $16 \mathrm{~mm}$. The percentage of medusae containing prey was $66.7 \%$. In total, 51 zooplanktonic prey were found in the stomachs. The number of preys for each medusa varied from 1 to 6 . The most frequent prey in the stomachs of medusae were the cladoceran Bosmina longispina (size: $0.4 \pm 0.1 \mathrm{~mm}, \mathrm{n}=11$ ) and cyclopoid copepods (size:

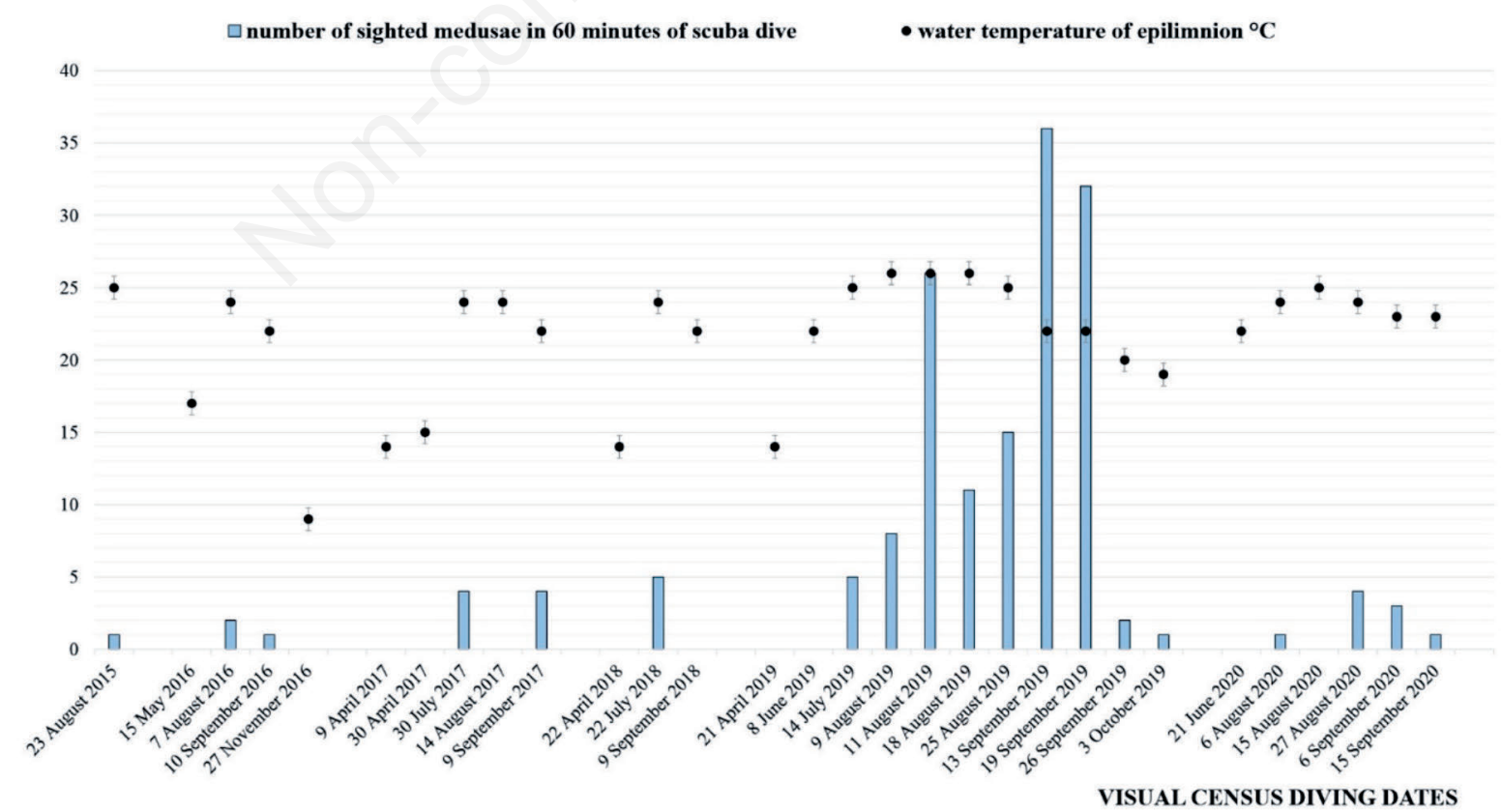

Fig. 2. Underwater sightings of Craspedacusta sowerbii medusae in the Large Lake of Monticolo/Montiggl during scuba dives in years 2015-2020. The number of sighted medusae in $60 \mathrm{~min}$ of a visual census dive is reported with indication of the water temperature of epilimnion (between 1 and $5 \mathrm{~m}$ of depth) for each diving date. 
$0.6 \pm 0.1 \mathrm{~mm}, \mathrm{n}=12$ ). The size range of prey was mostly between $0.3-0.8 \mathrm{~mm}$. The smallest was one single rotifer Keratella cochlearis $(0.1 \mathrm{~mm})$. In accordance with other studies (Dodson and Cooper, 1983; Spadinger and Maier, 1999; Pérez-Bote et al., 2006; Smith and Alexander, 2008; Stefani et al., 2010), the number of copepods and cladocerans exceeded the number of rotifers in all stomachs of medusae, although the individual density of rotifers in the pelagic zone was always higher than that of crustaceans in the years from 1981 to 2015 (source database of the Biological Laboratory, Agency for Environment and Climate Protection of the Autonomous Province Bolzano South Tyrol, Italy, 2020).

\section{CONCLUSIONS}

In the natural Large Lake of Monticolo/Montiggl medusae were observed in 6 consecutive summers from 2015 to 2020 with water temperature from $19^{\circ} \mathrm{C}$ to $26^{\circ} \mathrm{C}$. Polyps of $C$. sowerbii were recorded in the lake on the zebra mussels $D$. polymorpha in shallow water and on the undersides of artificial substrates. The polyp and medusa stages are only rarely reported together in the same aquatic ecosystem (Failla Siquier et al., 2017). Considering the commensalism between polyps of $C$. sowerbii and D. polymorpha described by Stanković and Ternjej (2010), the analyses of zebra mussels could be a simple method to check for the presence of $C$. sowerbii in various aquatic environments. Even though sightings of jellyfish are rare, this species may be more widespread in Italy than previously thought (Ciutti et al., 2017), because the small polyps tend to go unnoticed (Duggan and Eastwood, 2012). The rather simple collecting method via zebra mussels could also be used to examine a larger number of water bodies in order to identify the genetic lineages present in it. As there are now two distinct genetic lineages known to occur in Italy, perhaps places can be found where both co-occur. This would allow an easier evaluation of their species status. A good sampling strategy would be to investigate first populations in middle Italy and the southern tip of the peninsula. According to the lineages found, the subsequent sampling regions can then be narrowed down.

\section{ACKNOWLEDGMENTS}

The authors thank Benno Baumgarten for his help with microscope photography. Special thanks to Andrea Falcomatà for scuba diving together with the first author during sampling and census of medusae. We also kindly thank Federico Marrone and Luigi Naselli-Flores (University of Palermo, Italy) for the gift of a tissue sample from Sicily.
Massimo Morpurgo was supported by the research project of the Museum of Nature South Tyrol "Hydrozoa and Bivalvia in the lakes of Monticolo / Montiggl and Caldaro / Kaltern" funded by the Betrieb Landesmuseen / Azienda Provinciale dei Musei Altoatesini. We thank also Birgit Alber and Alan Prince for stylistic suggestions. We acknowledge the two anonymous referees for the helpful suggestions that have improved the clarity of our manuscript.

\section{Ethical standards}

The authors declare that this study complies with the current Italian and Swiss laws.

\section{REFERENCES}

Acker TS, Muscat AM, 1976. The ecology of Craspedacusta sowerbii Lankester, a freshwater hydrozoan. Am. Midl. Naturalist. 93:323-336.

Arbačiauskas K, Lesutienė J, 2005. The freshwater jellyfish (Craspedacusta sowerbii) in Lithuanian waters. Acta Zool. Lit. 15:54-57.

Badino G, Lodi E, 1972. The medusa Craspedacusta sowerbii Lankester (Limnomedusae) from Lake Sirio (Ivrea, Italy). Bull. Pesca Piscic. Idrobiol. 27:293-296.

Bekleyen A, Varol M, Gokot B, 2011. A new record of the freshwater jellyfish Craspedacusta sowerbii Lankester, 1880 (Hydrozoa) in Southeastern Anatolia (Turkey). Chin. J. Oceanol. Limnol. 29:366-368.

Boothroyd IKG, Etheredge MK, Green JD, 2002. Spatial distribution, size structure, and prey of Craspedacusta sowerbii in a shallow New Zealand lake. Hydrobiologia 468:23-32.

Caputo L, Huovinen P, Sommaruga R, Gómez I, 2018. Water transparency affects the survival of the medusa stage of the invasive freshwater jellyfish Craspedacusta sowerbii. Hydrobiologia. https://doi.org/10.1007/s1075 0-0183520-4

Cianfanelli S, Lori E, Bodon M, 2010. Dreissena polymorpha: Current status of knowledge about the distribution in Italy, p. 93-100. In: G. van der Velde, S. Rajagopal \& A. bij deVaate (Eds), The Zebra Mussel in Europe, Backhuys/ Margraf Publishers

Ciutti F, Flaim G, Cappelletti C, 2017. The jellyfish Craspedacusta sowerbii Lankester, 1880: new observations in Trentino lakes and distribution in Italy (in Italian). Biol. Amb. 31:174-177.

Cotta Ramusino M, 1972. On the presence of Craspedacusta sowerbyi Lank. in Italian waters (in French). Bull. Fr. Piscic. 245:147-150.

DeVries DR, 1992. The freshwater jellyfish Craspedacusta sowerbyi: a summary of its life history, ecology, and distribution. J. Freshw. Ecol. 7:7-16.

Dodson SI, Cooper SD, 1983. Trophic relationships of the freshwater jellyfish Craspedacusta sowerbyi Lankester 1880. Limnol. Oceanogr. 28:345-351.

Duggan IC, Eastwood KR, 2012. Detection and distribution of 
Craspedacusta sowerbii: observations of medusae are not enough. Aquat. Invasions 7:271-275.

Dumont HJ, 1994. The distribution and ecology of the fresh and brackish-water medusae of the world. Hydrobiologia 272:1-12.

Failla Siquier MG, Serra Alanis WS, Martinez Debat C, 2017. First record of Craspedacusta sowerbii Lankester, 1880 (Hydrozoa, Limnomedusae) in a natural freshwater lagoon of Uruguay, with notes on polyp stage in captivity. Braz. J. Biol. 77:665-672.

Folino-Rorem NC, Reid M, Peard T, 2016. Culturing the freshwater hydromedusa, Craspedacusta sowerbii under controlled laboratory conditions. Invertebr. Reprod. Dev. 60:17-27.

Fritz GB, Schill RO, Pfannkuchen M, Brümmer F, 2007. The freshwater jellyfish Craspedacusta sowerbii Lankester, 1880 (Limnomedusa: Olindiidae) in Germany, with a brief note on its nomenclature. J. Limnol. 66:54-59.

Fritz GB, Pfannkuchen M, Reuner A, Schill RO, Brümmer F, 2009. Craspedacusta sowerbii, Lankester 1880 - population dispersal analysis using COI and ITS sequences. J. Limnol. 68:46-52.

Fuentes R, Cárdenas L, Abarzua A, Caputo L, 2019. Southward invasion of Craspedacusta sowerbii across mesotrophic lakes in Chile: geographical distribution and genetic diversity for the medusa phase. Freshw. Sci. 38:193-202. https://doi.org/10.1086/701772

Gasith A, Gafny S, Hershkovitz Y, Goldstein H, Galil BS, 2011. The invasive freshwater medusa Craspedacusta sowerbii Lankester, 1880 (Hydrozoa: Olindiidae) in Israel. Aquat. Invasions 6:147-152.

Groppali R, 2013. New records of the freshwater jellyfish Craspedacusta sowerbyi in Lombardia and notes on its presence in Italy (Hydrozoa: Limnomedusa: Olindiidae) (in Italian). Pianura 30:109-117.

Heine JN (2011) Scientific Diving Techniques. A practical guide for the research diver. Second edition, Best Publishing Company, North Palm Beach: pp 232.

Jankowski T, 2000. Chemical composition and biomass parameters of a population of Craspedacusta sowerbii Lank 1880 (Cnidaria: Limnomedusa). J. Plankton Res. 22:13291340.

Jankowski T, 2001. The freshwater medusae of the world - a taxonomic and systematic literature study with some remarks on other inland water jellyfish. Hydrobiologia 462:91-113.

Jankowski T, Collins AG, Campbell R, 2008. Global diversity of inland water cnidarians. Hydrobiologia 595:35-40.

Karaouzas I, Zogaris S, Lopes-Lima M, Froufe E, Varandas S, Teixeira A, Sousa R, 2015. First record of the freshwater jellyfish Craspedacusta sowerbii Lankester, 1880 in Greece suggests distinct European invasion events. Limnology 16:171-177.

Kramp PL, 1961. Synopsis of the medusae of the world. Order Limnomedusae. J. Mar. Biol. Assoc. UK 40:213-236.

Lankester ER, 1880. On a new jelly-fish of the order Trachomedusae, living in fresh water. Nature 22:147-148.

Lewis C, Migita M, Hashimoto H, Collins AG, 2012. On the occurrence of freshwater jellyfish in Japan 1928-2011: eightythree years of records of mamizu kurage (Limnomedusae, Olindiidae). P. Biol. Soc. Wash. 125:165-179.
Lundberg S, Svensson JE, Petrusek A, 2005. Craspedacusta invasion in Sweden. Verh. Internat. Verein Limnol. 29: 899-902.

Lundberg S, Svensson JE, Petrusek A, 2007. Freshwater jellyfish Craspedacusta - single-sex populations evidence of repeated invasion (in Swedish). Fauna and Flora 102:18-22.

Medina-Gavilán JL, González-Duarte MM, 2018. A synthesis of known Iberian localities for Craspedacusta sowerbii Lankester, 1880 (Cnidaria: Hydrozoa): new record for Spain from low Guadalquivir River. Graellsia 74(2): e072. https://doi.org/10.3989/graellsia.2018.v74.193

Minchin D, Caffrey JM, Haberlin D, Germaine D, Walsh C, Boelens R, Doyle TK, 2016. First observations of the freshwater jellyfish Craspedacusta sowerbii Lankester, 1880 in Ireland coincides with unusually high water temperatures. Biol. Invasions Records 5:67-74.

Moreno-Leon MA, Ortega-Rubio A, 2009. First record of Craspedacusta sowerbyi Lankester, 1880 (Cnidaria: Limnomedusae: Olindiidae) in Mexico (Adolfo Lopez Mateos reservoir), with notes on their feeding habits and limnological dates. Biol Invasions 11:1827-1834.

Morpurgo M, Thaler B, 2002. Finding of Dreissena polymorpha (Pallas) (Mollusca, Bivalvia) in the Large Lake of Monticolo Montiggl, South Tyrol, Italy (in Italian). Gredleriana, 2:219222.

Morpurgo M, Alber R, 2015. First record of the freshwater jellyfish Craspedacusta sowerbii Lankester, 1880 (Cnidaria: Hydrozoa: Limnomedusae) in South Tyrol (Italy). Gredleriana 15:61-64.

Oualid JA, Iazza B, Tamsouri NM, El Aamri F, Moukrim A, López-González PJ, 2019. Hidden diversity under morphology-based identifications of widespread invasive species: the case of the "well-know" hydromedusa Craspedacusta sowerbii Lankester 1880. Anim. Biodivers. Conserv. 42:301-316. https://doi.org/10.32800/abc.2019. 42.0301

Pérez-Bote J, Muñoz A, Morán R, Roso R, Romero AJ, 2006. First record of Craspedacusta sowerbyi Lankester, 1880 (Cnidaria: Limnomedusae: Olindiidae) in the Proserpina Reservoir (Extremadura, SW Spain) with notes on their feeding habits. Bel J Zool 136:163-166.

Peterlin D, Tollardo M, Geier G, Tartarotti P, 2019. Climate Report n. 284 August 2019 Autonomous Province Bolzano / Bozen, Italy (in Italian). Available: http://meteo.provincia.bz.it/ pubblicazioni.asp Cited 31 Jan 2020.

Ramazzotti G, 1962. [Finding of the freshwater jellyfish Craspedacusta sowerbyi in the nearby of Lake Maggiore]. [Article in Italian]. Mem. Ist. Ital. Idrobiol. 15:175-181.

Rayner NA, 1988. First record of Craspedacusta sowerbyi Lankester (Cnidaria: Limnomedusae) from Africa. Hydrobiologia 162:73-77.

Rossi L, Lodi E, 1971. Finding of Craspedacusta sowerbyi Lankaster in some lakes of Piemonte (in Italian). Doriana 198:1-3.

Schifani E, Viviano A, Viviano R, Naselli-Flores L, Marrone F, 2018. Different lineages of freshwater jellyfishes (Cnidaria, Olindiidae, Craspedacusta) invading Europe: another piece of the puzzle from Sicily, Italy. Limnology 20:143-151. https://doi.org/10.1007/s10201-018-0560-4

Schuchert P, 2014. High genetic diversity in the hydroid 
Plumularia setacea: A multitude of cryptic species or extensive population subdivision? Mol. Phylogenet. Evol. 76:1-9. https://dx.doi.org/10.1016/j.ympev.2014.02.020

Schuchert P, 2018. DNA barcoding of some Pandeidae species (Cnidaria, Hydrozoa, Anthoathecata). Rev. Suisse Zool. 125(1):101-127. https://dx.doi.org/10.5281/zenodo.1196029

Schuchert P, 2019. The hydroid of the medusa Lizzia blondina Forbes, 1848. Mar. Biodivers. 49(4):1683-1693.

Smith AS, Alexander JE Jr, 2008. Potential effects of the freshwater jellyfish Craspedacusta sowerbii on zooplankton community abundance. J. Plankton Res. 30:1323-1327.

Spadinger R, Maier G, 1999. Prey selection and diel feeding of the freshwater jellyfish, Craspedacusta sowerbyi. Freshwater Biol. 41:567-573.

Stanković I, Ternjej I, 2010. New ecological insight on two invasive species: Craspedacusta sowerbii (Coelenterata: Limnomedusae) and Dreissena polymorpha (Bivalvia: Dreissenidae). J. Nat. Hist. 44:2702-2713.

Stefanelli A, 1948. A freshwater jellyfish of the genus Craspedacusta developed in a fish tank of the Institute (in Italian). Ital. J. Zool. 15:41-47.

Stefani F, Leoni B, Marieni A, Garibaldi L, 2010. A new record of Craspedacusta sowerbii, Lankester 1880 (Cnidaria, Limnomedusae) in Northern Italy. J. Limnol. 69:189-192.

Thaler B, Tait D, 1981a. [The Large Lake of Monticolo/Montiggl: geology, hydrography and morphology].[Article in Italian]. Ann. Lab. Biol. Prov. 2:105-112.

Thaler B, Tait D, 1981b. [The Small Lake of Monticolo/Montiggl: geology, hydrography and morphology].[Article in Italian]. Ann. Lab. Biol. Prov. 2:113-121.

Thaler B, Tait D, 1987. [The Large Lake of Monticolo/Montiggl. Limnological characterization based on research carried out in the period 1975-1985]. [Article in Italian]. Ann. Lab. Biol. Prov. 4:75-176.

Thomas IM, 1950. The medusa Craspedacusta in Australia. Nature 166:312-313.

Trentini M, 1993. [Finding of Craspedacusta sowerbyi (Coelenterata, Hydrozoa, Limnomedusae) in the valley of river Foglia (Province Pesaro)].[Article in Italian Quad. Stud. Nat. Romagna, 2:51-54.

Xu S, Wang D, 2009. Life cycle of Craspedacusta sowerbyi xinyangensis. Curr. Zool. 55:227-234.

Zhang LQ, Wang GT, Yao WJ, Li WX, Gao Q, 2009. Molecular systematics of medusae in the genus Craspedacusta (Cnidaria: Hydrozoa: Limnomedusae) in China with the reference to the identity of species. J. Plankton Res. 31:563-570.

Zou H, Zhang J, Li W, Wu S, Wang G, 2012. Mitochondrial genome of the freshwater jellyfish Craspedacusta sowerbyi and phylogenetics of Medusozoa. PLoS One 7:e51465. 